\title{
Are the Communists Dying Out in Russia?
}

\author{
D. Roderick Kiewiet \\ California Institute of Technology \\ and \\ Mikhail G. Myagkov \\ University of Oregon
}

April 2001

Paper prepared for delivery at the "INITIAL CONDITIONS AND THE TRANSITION ECONOMY IN RUSSIA: THE WEIGHT OF THE PAST IN COMPARATIVE PERSPECTIVE”, April 2001, Houston, TX

A part of this research was supported by an NCEEER Grant to the California Instuute of Technology 


\section{Introduction}

According to many observers of Russian politics, the 1996 presidential election, in which Gennady Zyuganov won 43 percent of the popular vote in the second round against Boris Yeltsin, was in all likelihood the "last hurrah" of the Communist Party of the Russian Federation. The reason for erroneous view was simple: support for the party was concentrated among elderly pensioners, while support for political and economic reform was strongest among the younger cohorts of voters. According to Vyacheslav Nikonov, a leading analyst of Russian politics, the communists were a dying breed: "There is no correlation between living conditions and the communist vote. The correlation is age" (quoted by Lally 1997).

A substantial body of survey data backed up Nikonov's assessment. In interviews conducted in the waning years of the Soviet Union, Finifter and Mickiewicz (1992) report finding that elderly respondents (those over age 60) were far less supportive than those in younger age groups of the basic tenets of political and economic reform. They were less likely to see the value of competitive elections and freedom of speech, less likely to assign responsibility for one's well-being to the individual rather than the state, and less tolerant of income disparities. ${ }^{1}$ Miller, Hesli, and Reisinger (1994), similarly, reported that in a series of surveys conducted between 1990 and 1992, elderly Russians were considerably more likely to agree that an orderly society took precedence over individual freedom, that Stalin was not being given enough credit for building socialism, and that political reform in Russia was advancing too rapidly. Similar findings abound, including those of Bahry (1993) and Reisinger et al. (1994).

To most Westerners it seems surprising that elderly Russians are so much more supportive of the communists, in that it was this generation that directly suffered the calamities wrought by Stalinism. There are two major explanations that are usually given as to why this is nevertheless the case. First, during the early, formative years of their life, the currently elderly were subject not only to the horrors of totalitarianism but also to "totalitarian socialization" (Gibson 1996). In the world in which they grew up, it was the 
Communist Party, unerringly directed by Comrade Stalin, that brought about rapid industrialization, victory in the Great Patriotic War, and Sputnik. This explanation thus posits a generational effect, as it is understood in cohort analysis. A similar phenomenon in this country is the association of Franklin Roosevelt and the Democratic Party with ending the Great Depression. Voters who entered the electorate at about this time, the "New Deal" Democrats, remained disproportionately supportive of the party over the course of their entire lifetimes (Andersen 1979).

The second major explanation was that elderly pensioners were badly injured by the reforms that ended the communist regime. In particular, the extremely high rates of inflation that occurred in 1992-94 effectively wiped out their retirement savings. Pensioners also experienced a degradation in medical care and other support services. This resulted not only from cuts in direct government expenditures, but also from the desire of newly privatized enterprises with newly enshrined profit motives to minimize social welfare expenditures on current and former employees. To be sure, retirement in the Soviet Union was never to be confused with that experienced in places like Ft. Lauderdale, Florida, but it did afford a certain modicum of security. But with the affluence of the New Russians there has also come the New Poor-the elderly pensioners one sees on the streets of Russian cities, selling off their belongings to help make ends meet (Varoli 1996).

As noted frequently in the Western news media, life expectancy in Russia, which was never all that high to begin with, fell dramatically in the 1990s, particularly among males. Table 1, taken from Hough, Davidheiser, and Lehmann (1996) reports mortality rates for various age cohorts of Russian men and women for the years between 1990 and 1994. As these data indicate, mortality rates for all cohorts rose, but the sharpest increases were among Russian men over the age of 60 . Based upon these figures, we can estimate that roughly one fifth of the voters who were pensioners at the time of the 1991 presidential election had died by the time of the 1996 election. 
Table 1 about here

The supporters of reform would thus seem to have time very much on their side. Granted, the transition to a more market-oriented economy may have cost millions of casualties among the elderly, but there are fewer of them today than there were yesterday, and there will be fewer tomorrow than there are today. In a recent prognosis on the future of Russian politics, Deputy Secretary of State Strobe Talbott (1997 put it this way:

Perhaps the most significant and hopeful statistic I've seen: although $65 \%$ of those Russians over the age of 65 think things got worse over the last year, $60 \%$ of those under 35 think things got better. So among the positive trends underway in Russia is perhaps the most basic of all, the one represented by the actuarial tables.

The 1999 Duma election and the 2000 presidential election in Russia came as a perfect tool to test the validity of this scenario. Indeed, as numbers in Table 2 show only about $50 \%$ of those receiving pensions in 1990 got to live long enough to see Boris Yeltsin resign and to participate in the latest election cycle.

Table 2 is about here

Thus, if Talbott's prediction was correct then the support for the communist party in 1999 and their leader Zuganov in 2000 should have dropped by the same factor. However, the election results suggest the opposite. In December of 1999, approximately 30\% of voters cast their ballots for the CPRF and their closest allies ("Communists for the USSR", "Stalin's Block" etc). This is almost identical to what they had gotten in December of 1995 (approx. 28\% of the vote). Genadii Zuganov received $30.2 \%$ of the popular vote in March of 2000, compared to 32\% support he enjoyed in the first round of the 1996 presidential elections. It is clear that those who hoped for the disappearence of the "reds" in the mortuaries got it wrong. But the question about the nature, source and the future of the support for the communist party remains open. An attempt to answer this question naturally leads us to two competing hypothesis: 
H1: The CPRF voters are widely distributed among various population groups, and the party's support is not related to a voter's age or social status.

H2: Most of its support CPRF receives from pensioners and elderly people. "New" pensioners start voting communist as soon as they enter that age group, even though they might have voted otherwise before.

If the first hypothesis holds then it implies Russian voters cast their ballots one way or another depending upon their approval or disapproval of the consequences that market reforms bring them, now and in the future. Support for continuing reform would thus depend upon the extent to which reforms are actually successful in improving economic conditions in general, and not just in redistributing resources to the young from the old. On the other hand if the second hypothesis is correct then it suggests that the CPRF is very successful in attracting new voters, and might remain a serious political force for years to come no matter what the government is doing against it.

\section{Analysis}

In order to get some purchase on this question we have undertaken an analysis that compares the size and nature of the "pensioner" vote in the 1991, 1996 and 2000 presidential elections. This analysis is based upon voting returns and demographic data, aggregated at the rayon level ${ }^{2}$ and consists of two major parts: comparison of 1991/1996 (part 1) and 1996/2000 (part 2) returns. Although we do not have observations from all rayons, we do have, as shown in Table 3, an entirely adequate and representative sample of 1436 rayons distributed across all major economic and political subdivisions of the country.

Table 3 about here 
The most straightforward way in which to test the hypothesis that support for the communists is literally dying out would be to regress change (between 1991 and 1996, and, then between 1996 and 2000) in the percentage of votes going to the communist candidate upon change in the percentage of pensioners in each rayon. The relative performance of the communists would be expected to decline in those rayons that lost the largest number of pensioners. This turned out not to be feasible, because in most rayons the percentage of pensioners changed very little over this ten-year period. It is hard to explain variance in the dependent variable with an independent variable that has little variance.

There is, however, another estimation strategy available. As indicated earlier, by our estimates roughly one-fifth of those who were pensioners in 1991 were gone by 1996 and about one-halve were gone by the year 2000. To the extent they were replaced by individuals from a younger, less Stalinist cohort, we would expect support for the communists in this category of voters to be diluted. We can thus estimate an equation of the following form:

$$
\frac{y^{1}}{y^{2}}=\alpha\left(\frac{1}{1}\right)+\mathrm{B}_{1}\left(\frac{X^{1}}{X^{2}}\right)+\left(\mathrm{B}_{2}-\mathrm{B}_{1}\right)\left(\frac{0}{X^{2}}\right)
$$

where:

$y^{1}=$ the percentage of vote won by the communist candidate in each rayon in the first presidential election (1991/1996).

$y^{2}=$ the percentage of vote won by the communist candidate in each rayon the second presidential election (1996/2000).

$\mathrm{X}^{1}=$ the percentage of pensioners in each rayon in the first presidential election year.

$\mathrm{X}^{2}=$ the percentage of pensioners in each rayon in the second presidential election year.

In the first part of our analyis we call the 1991 and 1996 as "first" and "second" election respectively. In the second part of the analysis we call the 1996 and 2000 elections as the "first" one and the "second" one. If support for the communists among pensioners was 
diluted between the first and the second elections, then in the manner described above, we would expect the coefficient for the pensioner vote in the second election relative to that in the first $\left(B_{2}-B_{1}\right)$ to be negative. In order to properly specify this equation we need to also estimate the cross-the-board changes in support for the communist candidate between the two elections. We thus specify a dummy variable for observations made in the second election, in addition to a constant term. We also specify dummy variables for each of the 48 regions and republics from which the rayons in our sample are drawn. This is necessary because of the substantial regional variation in support for the communist party.

Another complication we need to address derives from the fact that there were three major candidates in the 1991 presidential election-Boris Yeltsin, the communist candidate Nikolai Ryzhkov, and Vladimir Zhirinovsky, - two rounds in the 1996 presidential election and only one round in the 2000 presidential election. Rather than speculate as to the best way to specify the dependent variable, we thought a preferable strategy would be to run the regression on several different permutations. To the extent our results do not vary with the way we specify the dependent variable, we can be confident in their robustness. It should be noted that in some of these equations the dependent variable is pro-Yeltsin, and thus our expectations about the signs of the coefficients would be reversed.

At any rate, we used the following pairs of votes in the first part of the analysis: (1) for Ryzhkov in 1991, for Zyuganov in the first round of 1996; (2) for Ryzhkov in 1991, for Zyuganov in the second round of 1996; (3) for all candidates other than Yeltsin in 1991, for Zyuganov in the first round of 1996; (4) for Yeltsin in 1991, for Yeltsin in the first round of 1996; (5) for Yeltsin in 1991, for Yeltsin in the second round of 1996; (6) for Yeltsin in 1991, for Yeltsin or Lebed in the first round of 1996. Also, simply out of curiosity we ran the regression using Zhirinovsky's votes in 1991 and in the first round of 1996.

In the second part of the analysis the following pairs ov votes have been used: (1) for Zuganov in the first round in 1996, for Zuganov in 2000; (2) for all candidates other than 
Yeltsin in 1996 first round, for Zuganov in 2000; (3) for Yeltsin in the first round of the 1996, for Putin in 2000,.

Results of the 1991/1996 part of our regression analyses are reported in Table 4. The top number in each entry is the regression coefficient, the bottom number the standard error. Note also that coefficients associated with the 48 regional dummy variables are not reported. Looking first at the coefficients associated with the pensioner vote in the 1991 election, we see that this category of voters was quite supportive of Ryzhkov and correspondingly unsupportive of Yeltsin. This is exactly what the findings from the survey data discussed previously would have portended. But contrary to the hypothesis that pensioners' support for the communists had become diluted over the intervening five years, we see that the elderly were actually far more supportive of the communist candidate in 1996 than they had been previously. Clustered around .5, the coefficients we estimated in the first three equations for the "pensioners, second election" term must be added to the coefficients of the "pensioners, first round" term (which average about .3) to gauge their effect. Our results thus indicate that an increase of one in the percentage of pensioners in a rayon would lead to a .8 percent increase in the percentage of votes won by Zyuganov.. Support for the communists among Russian pensioners thus became more concentrated, not diluted.

\section{Table 4 about here}

Turning to the other equations reported in Table 4, we see that the coefficients in the Yeltsin equations are smaller, but still sizable. They thus indicate that pensioners' opposition to Yeltsin, while already quite strong in 1991, was much stronger in 1996. We can thus be confident that our results do not depend upon any particular specification of the dependent variable. Finally, we see that although pensioners were somewhat more supportive of Zhirinovsky in 1991, by 1996 they were no more likely than younger cohorts of Russians to vote for him.

Results of the 1996/2000 part of the analysis are reported in Table 5. It is not surprising that the first row of coefficients is roughly similar to the sum of the first and second rows 
in Table 4. These coefficients show pensioners' support for a particular candidate in the 1996 election. It is interesting to note that the much smaller coefficients in the second row do not turn opposite to the coefficients in the first row. This indicates that pensioners as a group stayed loyal to the communist party despite large degree of "rotation" within their (pensioners) ranks. Table 5 also shows that Putin did not enjoy much of support from the elderly. This is somewhat similar to Yeltsin's situation in 1991 and 1996. Finally, it is interesting to note that Yeltsin's 1996 voters did not go "all as one" to Vladimir Putin, implying that Putin must have gotten most of his votes from "elsewhere".

Table 5 about here

\section{Discussion}

"Pensioners are paid very little, but at least they get something...Nobody notices us."

---Nina Matskevich, 49-year-old unemployed accountant The most ready explanation of our findings, which run utterly counter to the dilution hypothesis, involves timing: while Russian pensioners tended to oppose Yeltsin in 1991 because of their apprehension over the political and economic reforms he was promoting, they strongly opposed him in 1996 because by then they had experienced the severe, economic dislocations the reforms engendered, and they kept voting communist in 2000 for the reason that the government did not improve their lives. There is surely some truth to this, but we doubt that it is the full story. First, the regression equations we estimated included a dummy variable for the 1996 (2000) election, which should have registered across-the-board changes in support for the communists and opposition to Yeltsin (Putin). The pensioner variables thus register effects over and above the nation-wide swing, and so this interpretation would imply that pensioners were especially hard hit.

According to our reading of the situation, however, this was not the case. The pensions Russians receive are certainly quite modest, but payments have been indexed to inflation and are probably not much lower in real terms than they were when the reforms began. Although whatever savings they might have had in Sberbank were wiped out, most Russians have long kept much of their savings in other forms. They also received title to 
their apartments; given the high property values of Moscow and other major cities, this means that they would experience a windfall profit were they to sell their apartment. This is not meant to minimize the very difficult material conditions under which many elderly Russians live, but only to note, as Varoli (1996) reports, that "Their plight is not as severe as portrayed by the mass media" (p. 11).

In our view, it was not pensioners, but rather Russian workers who were approaching retirement who were disproportionately injured by the transition to a more marketoriented economy. They, too, suffered the loss of savings, but in many cases they also lost their jobs. Although many such workers remain on the company payroll, there is in fact no work for them and they are infrequently paid. Unlike younger workers, they simply lack the time to learn the new skills and new habits that the economy now calls for.

Between the three presidential elections, then, those who had been pensioners in 1991 were joined by large numbers of new pensioners who had suffered badly during the final years of their working lives. While not officially counted as unemployed, they in fact had no work and received little pay. For such people, becoming old enough to receive a pension actually marked an improvement in their material conditions. As retrospective economic voters, they thus strongly supported Zyuganov in 1996 and 2000. In short, the "new" pensioners who entered this category between 1991 and 1996 were substantially more supportive of the communists than those who had died. That support remained intact between 1996 and 2000 presidential campaigns.

We therefore think the second hypothesis holds as a much more probable one. This is probably a pretty good news for Genadii Zuganov and co. According to data on the age structure of the Russian population, there are many millions of people over fifty years old and thus too old to smoothly transition to the ways of the new economy. Support for the communists is concentrated among the old, but this will remain a very large category of voters for many years to come. 


\section{Endnotes}

1. The category of "elderly" needs to be adjusted downward in a country in which normal retirement age for women has long been 55, 60 for men, and where current male life expectancy is about 58 .

2. We are indebted to Sergei Beriozkin and to the late Alexandr Sobianin for making these data available to us.

\section{References}

Andersen, Kristi. 1979. The Creation of a Democratic Majority, 1928-1936. Chicago: University of Chicago Press.

Bahry, Donna. 1993. "Society Transformed? Rethinking the Social Role of Perestroika." Slavic Review 52:512-54.

Gibson, James. 1996. “A Mile Wide But an Inch Deep (?): The Structure of Democratic Commitments in the Former USSR.” American Journal of Political Science 40:396-420.

Finifter, Ada, and Ellen Mickiewicz. 1992. "Redefining the Political System of the USSR: Mass Support for Political Change.” American Political Science Review 86:857-74.

Hough, Jerry, Evelyn Davidheiser, and Susan Lehman. 1996. The 1996 Russian Presidential Election. Washington: Brookings Institution Press.

Lally, Kathy. 1997. “'Mr. Nyets’ Day is Almost Over.” Baltimore Sun, November 7. Miller, Arthur, Vicki Hesli, and William Reisinger. 1994. "Reassessing Mass Support for 
Political and Economic Change in the Former USSR.” American Political Science Review 88:399-411.

Reisinger, William, Arthur Miller, Vicki Hesli, and Kristen Maher. 1994. "Political Values in Russia, Ukraine, and Lithuania: Sources and Implications for Democracy." British Journal of Political Science 45:183-223.

Talbott, Strobe. 1997. "The End of the Beginning: The Emergence of a New Russia." Address given at Stanford University, September 19.

Varoli, John. “There Are More 'New Poor' Than 'New Russians.'” Transition 2-20:6-11. 
Table 1. Mortality Rates in Russia per 1,000 Population, by Age and Gender, 1990-94

\begin{tabular}{cccccc}
\hline Age & $\mathbf{1 9 9 0}$ & $\mathbf{1 9 9 1}$ & $\mathbf{1 9 9 2}$ & $\mathbf{1 9 9 3}$ & $\mathbf{1 9 9 4}$ \\
\hline Men & & & & & \\
$40-44$ & 7.6 & 8.0 & 9.8 & 13.3 & 15.2 \\
$45-49$ & 11.7 & 11.6 & 13.8 & 17.8 & 20.8 \\
$50-54$ & 16.1 & 16.6 & 19.4 & 26.3 & 29.1 \\
$55-59$ & 23.4 & 23.3 & 25.3 & 31.3 & 38.2 \\
$60-64$ & 34.2 & 34.6 & 36.9 & 46.3 & 61.0 \\
$65-69$ & 48.0 & 47.3 & 49.4 & 59.4 & 64.0 \\
& & & & & \\
Women & & & & & \\
$40-44$ & 2.4 & 2.6 & 2.8 & 3.7 & 4.2 \\
$45-49$ & 3.8 & 3.8 & 4.2 & 6.4 & 8.2 \\
$50-54$ & 5.4 & 6.6 & 8.1 & 7.9 & 8.0 \\
$55-59$ & 8.6 & 8.6 & 9.1 & 10.9 & 12.3 \\
$60-64$ & 13.5 & 13.6 & 14.4 & 16.7 & 18.4 \\
$65-69$ & 22.0 & 22.0 & 22.6 & 26.6 & 27.1 \\
& & & & & \\
\hline
\end{tabular}

Source: Rossiiskii statisticheskii ezhegodnik (Moscow: Groskomstat, 1996), p. 33. (Reprinted in Hough, et al., p. 94.) 
Table 2. Distribution of Russian population by age and gender 1989-1999

(in thousands of people)

\begin{tabular}{|c|c|c|c|c|c|c|}
\hline & \multicolumn{3}{|c|}{1989} & \multicolumn{2}{c|}{1999} \\
\hline Age & Total & Males & Females & Total & Males & Females \\
\hline $0-6$ & 16814 & 8559 & 8254 & 9646 & 4950 & 4696 \\
\hline $7-15$ & 19181 & 9729 & 9451 & 20688 & 10551 & 10137 \\
& & & & & & \\
\hline $\begin{array}{c}\text { Males } \\
16-59 \\
\text { Females } \\
16-54\end{array}$ & 83746 & 43440 & 40306 & 85547 & 43999 & 41547 \\
\hline $\begin{array}{c}\text { Males } \\
60-\end{array}$ & 27195 & 6945 & 20249 & & & \\
Females & & & & & & \\
\hline $55-$ & & & & & & \\
\hline $45-49$ & 7954 & 3760 & 4187 & 11137 & 5335 & 5894 \\
\hline $50-54$ & 9593 & 4453 & 5139 & 6997 & 3264 & 3733 \\
\hline $55-59$ & 8399 & 3719 & 4679 & 7094 & 3091 & 4003 \\
\hline $60-64$ & 8360 & 3239 & 5120 & 8105 & 3391 & 4713 \\
\hline $65-69$ & 4510 & 1367 & 3142 & 6609 & 2529 & 4080 \\
\hline $70-74$ & 2652 & 1011 & 2641 & 5935 & 1903 & 4031 \\
\hline $75-79$ & 3333 & 819 & 2513 & 2812 & 682 & 2130 \\
\hline $80-84$ & 1769 & 364 & 1405 & 1635 & 345 & 1289 \\
\hline $85-$ & 890 & 143 & 746 & 1343 & 256 & 1086 \\
\hline
\end{tabular}

Source: Socialno-ekonomicheskoe polozhenie Rossiiin 1999 (Moscow: Groskomstat, 2000), p. 28. 
Table 3. Regional Breakdown of Rayon-Level Sample

\begin{tabular}{ll}
\multicolumn{1}{c}{ Central } \\
\hline \\
Moscow & \\
Briansk & 33 \\
Vladmir & 31 \\
Vanovo & 26 \\
Kaluga & 26 \\
Kostroma & 26 \\
Orel & 24 \\
Riazan & 26 \\
Smolensk & \\
Tver & 27 \\
Tula & 38 \\
Yaroslavl & 17 \\
& 18 \\
& \\
\multicolumn{1}{c}{ Central-"Black Soil" } & \\
\hline Belgorod & \\
Voronezh & 26 \\
Kursk & 37 \\
Lipetsk & 30 \\
\end{tabular}

\begin{tabular}{ll}
\multicolumn{2}{c}{ Northwestern } \\
\hline St. Petersburgh Region & 17 \\
Pskov & 26
\end{tabular}

\begin{tabular}{lr}
\multicolumn{2}{c}{ Northern } \\
\hline Arkhangelsk & 23 \\
Vologda & 28 \\
Murmansk & 14 \\
Karelia Republic & 18 \\
$\quad$ Komi Republic & 19
\end{tabular}

Volgograd
Penza

Samara 34

Saratov 47

Ulianovsk 23

Kalmikia Republic $\quad 14$

Volga-Viatka

Kirovsk

El Republic Mordovia Republic

Chuvashia Republic

17

35 Mari-

23

25

\section{Northern Caucasus}

Adygeiya Republic 8

Karachaevo-Cherkess Repbulic 9 Rostov 52

Kab. Balkar. Republic 11

North-Ossetia 8

Ingushetia Republic

Ural

\begin{tabular}{lr}
\hline \multicolumn{1}{c}{ Kurgan } & 24 \\
Orenburg & 45 \\
Perm & 35 \\
Komi-Perm Autonomous Region & 6 \\
Sverdlovsk & 54 \\
Chelyabinsk & 29 \\
Bashkiria & 63
\end{tabular}

Volga 
Table 4. Pensioners' Choices in Russian Presidential Elections, 1991-96

\begin{tabular}{|c|c|c|c|c|c|c|c|}
\hline Variable & $\begin{array}{c}\text { Ryzhkov 91 } \\
\text { Zyuganov 96-1 }\end{array}$ & $\begin{array}{c}\text { Ryzhkov } 91 \\
\text { Zyuganov 96-2 }\end{array}$ & $\begin{array}{l}\text { Anti-Yeltsin } 91 \\
\text { Zyuganov 96-1 }\end{array}$ & $\begin{array}{l}\text { Yeltsin 91 } \\
\text { Yeltsin 96-1 }\end{array}$ & $\begin{array}{l}\text { Yeltsin } 91 \\
\text { Yeltsin 96-2 }\end{array}$ & $\begin{array}{c}\text { Yeltsin 91 } \\
\text { Yeltsin+Lebed 96-1 }\end{array}$ & $\begin{array}{c}\text { Zhirinovsky } 91 \\
\text { Zhirinovsky 96-1 }\end{array}$ \\
\hline Constant & $\begin{array}{c}4.7 \\
(2.1)\end{array}$ & $\begin{array}{l}6.8 \\
(2.0)\end{array}$ & $\begin{array}{l}22.2 \\
(2.5)\end{array}$ & $\begin{array}{l}78.8 \\
(2.2)\end{array}$ & $\begin{array}{l}77.7 \\
(2.4)\end{array}$ & $\begin{array}{l}80.7 \\
(2.3)\end{array}$ & $\begin{array}{c}0.4 \\
(0.6)\end{array}$ \\
\hline $\begin{array}{l}\text { Second } \\
\text { Election }\end{array}$ & $\begin{array}{c}5.6 \\
(.19)\end{array}$ & $\begin{array}{l}11.3 \\
(1.9)\end{array}$ & $\begin{array}{l}-19.5 \\
(2.3)\end{array}$ & $\begin{array}{l}-9.5 \\
(2.1)\end{array}$ & $\begin{array}{l}13.3 \\
(2.2)\end{array}$ & $\begin{array}{c}4.9 \\
(2.1)\end{array}$ & $\begin{array}{c}0.6 \\
(0.6)\end{array}$ \\
\hline $\begin{array}{l}\text { Pensioners, } \\
\text { First Election }\end{array}$ & $\begin{array}{l}.29 \\
(.05)\end{array}$ & $\begin{array}{l}.19 \\
(.05)\end{array}$ & $\begin{array}{l}.28 \\
(.06)\end{array}$ & $\begin{array}{l}-.33 \\
(.06)\end{array}$ & $\begin{array}{l}-.28 \\
(.06)\end{array}$ & $\begin{array}{l}-.42 \\
(.05)\end{array}$ & $\begin{array}{l}.16 \\
(.02)\end{array}$ \\
\hline $\begin{array}{l}\text { Pensioners, } \\
\text { Second } \\
\text { Election }\end{array}$ & $\begin{array}{l}.45 \\
(.06)\end{array}$ & $\begin{array}{l}.55 \\
(.06)\end{array}$ & $\begin{array}{c}.52 \\
(0.8)\end{array}$ & $\begin{array}{l}-.22 \\
(.07)\end{array}$ & $\begin{array}{l}-.45 \\
(.08)\end{array}$ & $\begin{array}{l}-.23 \\
(.07)\end{array}$ & $\begin{array}{l}-.15 \\
(.02)\end{array}$ \\
\hline $\mathrm{R}^{2}(\operatorname{adj})$ & .64 & .74 & .46 & .59 & .45 & .46 & .43 \\
\hline
\end{tabular}


Table 5. Pensioners' Choices in Russian Presidential Elections, 1996-00

\begin{tabular}{|c|c|c|c|}
\hline Variable & $\begin{array}{c}\text { Zyuganov 96-1 } \\
\text { Zuganov } 2000\end{array}$ & $\begin{array}{l}\text { Anti-Yeltsin } 96 \\
\text { Zuganov } 2000\end{array}$ & $\begin{array}{l}\text { Yeltsin 96-1 } \\
\text { Putin 2000 }\end{array}$ \\
\hline Constant & $\begin{array}{c}5.2 \\
(3.1)\end{array}$ & $\begin{array}{l}17.8 \\
(3.1)\end{array}$ & $\begin{array}{l}83.2 \\
(3.5)\end{array}$ \\
\hline $\begin{array}{l}\text { Second } \\
\text { Election }\end{array}$ & $\begin{array}{l}1.4 \\
(.46)\end{array}$ & $\begin{array}{l}-15.3 \\
(2.4)\end{array}$ & $\begin{array}{l}17.5 \\
(1.9)\end{array}$ \\
\hline $\begin{array}{l}\text { Pensioners, } \\
\text { First Election }\end{array}$ & $\begin{array}{c}.81 \\
(.11)\end{array}$ & $\begin{array}{l}.77 \\
(.7)\end{array}$ & $\begin{array}{l}-.81 \\
(.14)\end{array}$ \\
\hline $\begin{array}{l}\text { Pensioners, } \\
\text { Second } \\
\text { Election }\end{array}$ & $\begin{array}{c}.03 \\
(.004)\end{array}$ & $\begin{array}{l}-.01 \\
(.02)\end{array}$ & $\begin{array}{c}.34 \\
(0.1)\end{array}$ \\
\hline $\mathrm{R}^{2}$ (adj) & .73 & .69 & .38 \\
\hline
\end{tabular}

